\title{
HYDRAULIC PROPERTIES OF CARBONATE ROCKS FROM SLOVAKIAN BOREHOLE DATABASE
}

\author{
HIDRAVLIČNE LASTNOSTI KARBONATNIH KAMNIN \\ IZ PODATKOVNE BAZE SLOVAŠKIH VRTIN
}

\author{
Peter MALÍK ${ }^{1} \&$ Jaromír ŠVASTA ${ }^{1}$
}

\begin{abstract}
UDC 556.3:552.54(437.6)

Peter Malík \& Jaromír Švasta: Hydraulic Properties of Carbonate Rocks from Slovakian Borehole Database

Using archival hard copy records on 22,922 wells and hydrogeological boreholes, maintained since 1950's on the territory of Slovak Republic, a spatial database was developed. If possible, each borehole was linked to a certain aquifer or aquifer lithological type, according to its screened interval. Wells with ambiguous position of open casing were excluded from further processing to obtain distinct relation of pumping rate to lithology. Using stored records of hydraulic tests, each pumping rate was processed to obtain uniformly calculated "standard" specific capacity. These values were subsequently used to re-interpret hydraulic parameters. Based on standardized specific capacity data, estimates of transmissivity $\left(T\right.$; in $\left.\mathrm{m}^{2} \cdot \mathrm{s}^{-1}\right)$ and hydraulic conductivity $(K$; in $\mathrm{m} \cdot \mathrm{s}^{-1}$ ) for each well were calculated and linked to corresponding aquifer type. From these, hydraulic properties of limestones (238 boreholes), dolomites (463 boreholes) and granitoid rocks (96 boreholes) are compared. As anticipated, geometrical mean of transmissivity was low for granitoids $\left(6.51 \cdot 10^{-5} \mathrm{~m}^{2} \cdot \mathrm{s}^{-1}\right)$ and in one order of magnitude higher for limestones $\left(6.16 \cdot 10^{-4} \mathrm{~m}^{2} \cdot \mathrm{s}^{-1}\right)$, due to its enhancement by karstification. The highest observed value of mean transmissivity, two times higher than that found for limestones, was obtained for dolomitic aquifers $\left(1.04 \cdot 10^{-3} \mathrm{~m}^{2} \cdot \mathrm{s}^{-1}\right)$. Dolomitic aquifers also show the highest median values of hydraulic conductivity $\left(3.21 \cdot 10^{-5} \mathrm{~m} \cdot \mathrm{s}^{-1}\right)$, in one order of magnitude higher than granitoids $\left(2.10 \cdot 10^{-6} \mathrm{~m} \cdot \mathrm{s}^{-1}\right)$ and three times higher than limestones $\left(9.45 \cdot 10^{-6} \mathrm{~m} \cdot \mathrm{s}^{-1}\right)$. In comparison with limestones, dolomites seem to be slightly more homogeneous in aquifer properties; also several lithological types there show similarities in both $\boldsymbol{T}$ and $\boldsymbol{K}$. Some limestone lithofacies (Steinalm and Raming), seem to have lower transmissivity and hydraulic conductivity comparing to other limestones types (Dachstein, Gutenstein, Wetterstein). The data on hy-
\end{abstract}

\section{Povzetek}

UDK 556.3:552.54(437.6)

Peter Malík \& Jaromír Švasta: Hidravlične lastnosti karbonatnih kamnin iz podatkovne baze slovaških vrtin

S pomočjo arhivskih podatkov o 22.922 geoloških in hidrogeoloških vrtinah, zbranih na ozemlju Slovaške Republike od 50-ih let dalje, je bila izdelana prostorsko pozicionirana podatkovna baza. Kjer je bilo mogoče, je bila vsaka vrtina navezana na določen vodonosnik ali litološki tip vodonosnika glede na položaj filtrskega odseka. Vrtine z nezanesljivo lokacijo nezacevljenega dela so bile izključene iz nadaljnje obdelave, da bi dobili jasno zvezo med načrpano količino in litologijo. $\mathrm{Z}$ uporabo shranjenih podatkov hidravličnih testov je bil vsak donos vrtin obdelan, da bi dobili enotno izračunano »standardno« specifično izdatnost. Te vrednosti so bile kasneje uporabljene za re-interpretacijo hidravličnih parametrov. $\mathrm{Na}$ podlagi podatkov standardiziranih specifičnih izdatnosti sta bili za vsako vrtino izračunani transmisivnost $\left(\boldsymbol{T} ; \mathrm{v} \mathrm{m}^{2} \cdot \mathrm{s}^{-1}\right)$ in koeficient prepustnosti $\left(\boldsymbol{K} ; \mathrm{v} \mathrm{m} \cdot \mathrm{s}^{-1}\right)$ ter kasneje navezane na ustrezen tip vodonosnika. Od tod so bile primerjane hidravlične značilnosti apnencev (238 vrtin), dolomitov (463 vrtin) in granitoidnih kamnin (96 vrtin). Kot je bilo pričakovano, je bila geometrična srednja vrednost transmisivnosti najnižja za granitoide $\left(6.51 \cdot 10^{-5} \mathrm{~m}^{2} \cdot \mathrm{s}^{-1}\right)$ in $\mathrm{za}$ en velikostni red višje za apnence $\left(6.16 \cdot 10^{-4} \mathrm{~m}^{2} \cdot \mathrm{s}^{-1}\right)$ zaradi zakraselosti. Najvišja zabeležena vrednost srednje transmisivnosti, dvakrat večja od vrednosti za apnence, je bila dobljena za dolomitne vodonosnike $\left(1.04 \cdot 10^{-3} \mathrm{~m}^{2} \cdot \mathrm{s}^{-1}\right)$. Dolomitni vodonosniki kažejo tudi najvišje srednje vrednosti koeficientov prepustnosti $\left(3.21 \cdot 10^{-5} \mathrm{~m} \cdot \mathrm{s}^{-1}\right)$, za en velikostni razred višje kot pri granitoidih $\left(2.10 \cdot 10^{-6} \mathrm{~m} \cdot \mathrm{s}^{-1}\right)$ in trikrat višje kot pri apnencih $\left(9.45 \cdot 10^{-6} \mathrm{~m} \cdot \mathrm{s}^{-1}\right)$. V primerjavi $\mathrm{z}$ apnenci se zdijo dolomiti za malenkost bolj homogeni v lastnostih vodonosnikov. Nekaj litoloških tipov kaže tudi podobnosti v $\boldsymbol{T}$ in $\boldsymbol{K}$. Za nekaj vrst apnencev (Steinalm in Raming) se zdi, da imajo nižjo transmisivnost in koeficient prepustnosti $\mathrm{v}$ primerjavi z ostalimi (Dachstein, Gutenstein, Wetterstein). Podatki o hidroloških lastnostih vseh teh trdih kamnin kažejo

\footnotetext{
${ }^{1}$ State Geological Institute of Dionýz Štúr, Mlynská dolina 1, 81704 Bratislava, Slovakia, e-mail: peter.malik@geology.sk, jaromir.svasta@geology.sk
}

Received/Prejeto: 24.11.2009 
draulic properties of all these hard rocks show lognormal statistical distribution and high heterogeneity.

Keywords: hydrogeological boreholes, standard specific capacity, transmissivity, hydraulic conductivity, hard rocks, karstified rocks. lognormalno statistično porazdelitev in visoko stopnjo heterogenosti.

Ključne besede: hidrogeološke vrtine, standardna specifična izdatnost, transmisivnost, koeficient prepustnosti, trde kamnine, zakrasele kamnine.

\section{INTRODUCTION}

The investigation of hydraulic properties of hard rocks is more challenging than similar in porous media. Rockmass hydraulic properties are the key factor in controlling groundwater flow and thus are interesting from the point of view of groundwater supply and protection of groundwater resources. In karst aquifers, traditional concept of hydraulic conductivity has no physical meaning in the case of conduit flow (Kresic 2007) and represents a "lumped parameter" describing properties of "equivalent porous medium". Aquifer tests in karst should be designed, managed and interpreted with regard to aquifer heterogeneity, multiple porosity and anisotropy. However, such precise karst aquifer testing is rare and usually not included in the routine of drilling companies or water supply consultants. With lack of relevant data, any estimate of hydraulic conductivity or transmissivity can help in solving practical problems on local scale. Estimation of transmissivity $\boldsymbol{T}$ or hydraulic conductivity $\boldsymbol{K}$ from specific capacity is a quick method of acquiring hydraulic aquifer properties. Such an approach was discussed mostly for porous aquifer media (starting from e.g., Thomasson et al. 1960; Theis 1963; Jetel 1964, 1985) but some authors had also been dealing with similar techniques applied for fractured or karst rocks (El-Naqua 1994; Mace 1997; Verbovšek 2008). El-Naqua (1994) used empirical correlation of 237 transmissivity/specific capacity pairs in fractured carbonate aquifer, Hamm et al. (2005) performed similar correlation of 117 time-drawdown datasets from 116 wells in volcanic aquifer. Mace (1997) had examined the uncertainty in well loss estimates (from pipe-flow theory) to link specific capacity, influenced by well loss, and transmissivity of karst aquifer. Resulting empirical relation was different from such relations in other aquifer types and pointed on the potential errors in well loss estimates. Razack and Lasm (2006) also found significant statistical relationship between transmissivity and the specific capacity in fractured hard rock aquifer using data from 118 measured transmissivity data points. Verbovšek (2008) correlated $\boldsymbol{T}$ and specific capacity from 298 wells in dolomitic aquifers, showing that in this rock media the $\mathrm{T}-\mathrm{Q} / \mathrm{s}$ correlation coefficient does not increase with logarithmic transformation of the data. One should note that the spatial distribution of permeability in hard rocks shows specific irregularities that should be taken into account in the assessment and use of hydraulic parameters: (exponential) decrease of permeability with depth, specific relation between permeability and lithology, near-surface zone development, significance of fracture zones and spatial nonuniformity of transmissivity in the near-surface zone. Four quantitatively different categories of transmissivity related to the geomorphology of the relief were distinguished (Jetel 1990), particularly the valley bottom transmissivity (determined usually by aquifer tests in wells) and the much lower "slope transmissivity".

In this study, specific capacity data were also used to determine mean transmissivity $\boldsymbol{T}$ and hydraulic conductivity $\boldsymbol{K}$ of limestone, dolomitic and granitoid aquifers. These were estimated by individual re-interpretation of individual pumping tests, using unified "standard" specific capacity data to eliminate influences of differently performed pumping tests. Calculation of "logarithmical conversion differences" - parameters concerning hydraulic resistivities of both wells and aquifers was also employed. Set of hydraulic parameters, calculated in this way, was then linked to various aquifer types. One should still keep in mind the extremely enhanced heterogeneity, multiple porosity and anisotropy especially for karst aquifers. The scale effect, i.e., the dependency of hydraulic properties with scale of their measurement (Schulze-Makuch et al. 1999), plays also an important role in fractured and karst rock media. 


\section{BRIEF CHARACTERISTICS OF SLOVAKIAN CARBONATE ROCKS}

Central European spatial position of Slovak Republic (Fig. 1) and geology of West Carpathians imprint the hydrogeological character of the country. Although carbonate rocks in West Carpathians can be found in Palaeozoic metamorphic units, (mostly Carboniferous, but also Permian or Late Palaeozoic), they usually form only several meters thin beds and are of very limited outcropping extent. The vast majority of carbonate rocks are therefore Mesozoic - mostly Middle and Upper Triassic limestone/dolomite units. Average specific groundwater runoff from these carbonates varies from 5.0 up to $22.0 \mathrm{~L} \cdot \mathrm{s}^{-1} \cdot \mathrm{km}^{-2}$. These are mostly a part of so called core mountain units, where cores built by granitoids and metamorphic rocks are enveloped by autochthonous Mesozoic sediments and overthrusted by Mesozoic nappe systems (Fig. 2). Lower Triassic, Jurassic and Cretaceous sediments with different lithology (quartzites, shales, sandstones, marly limestones, etc.) are considered as regional aquitards. Some occurrences of carbonates are found in Paleogene and Neogene complexes, but - like in Palaeozoic - with very limited thicknesses and spatial extension. look, disregarding their limestone/dolomite lithologies, these are characterised in stratigraphical order:

- Gutenstein limestones represent a restricted shallow basin facies of the Anisian age ( 237-245 Ma), dark bedded, black micritic, very poorly fossiliferous and partly dolomitic limestones;

- Steinalm limestones are lightgray platform carbonate facies of Anisian section ( 237-245 Ma), built up mainly by fragments of Chlorophyceans and tubes of Dasycladaceans;

- Wetterstein dolomites are thick-bedded, finecrystalline, locally (in higher sections) banded or laminated, formed under lagoonal conditions in Upper Anisian - Ladinian ( 228-240 Ma);

- Ramsau dolomites (Anisian - Carnian; 217-237 $\mathrm{Ma})$ are thick-bedded $(10-50 \mathrm{~cm})$ or massive dolomicritic, dolopelmicritic, dolobiomicritic or dolosparitic rocks, in lower positions rich in crinoids;

- Wetterstein limestones (Ladinian to Lower Carnian; 222-237 Ma) are rich in algal detritus, Dasycladaceans and sponges, sometimes affected by irregular cloudy dolomitisation;

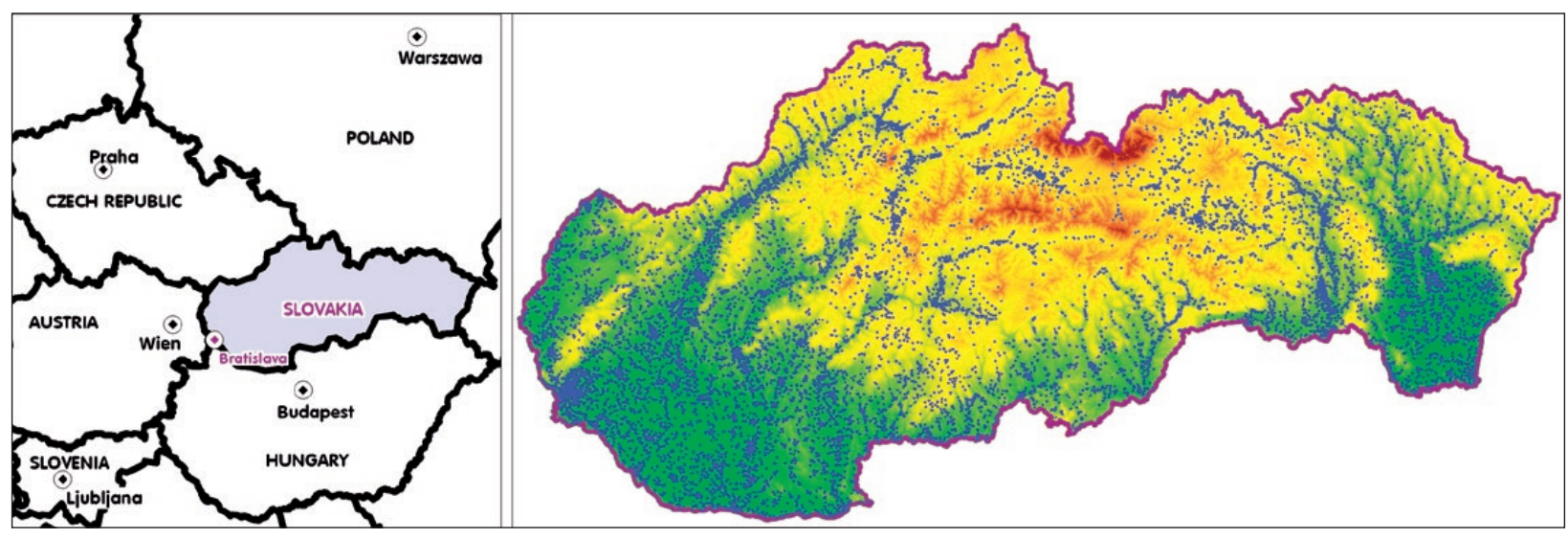

Fig. 1: Locations of all interpreted wells (blue points) on Slovak territory.

Therefore, in this study, we are dealing with only Middle and Upper Triassic limestones and dolomites. More accurate division of their individual lithological types, if sufficiently high population of hydraulically tested boreholes was found, is also included in this study. In dolomites, following lithotypes were studied: Wetterstein dolomites, "grey" dolomites, Ramsau and "hauptdolomites"/Main dolomites. Limestone aquifers were divided into Gutenstein, Steinalm, Raming, Wetterstein and Dachstein limestones (litostratigraphy of West Carpathian Mesozoic is close to Eastern Alpine, as for neighbourhoods of Tethydian sedimentary basins). In closer
- "grey" dolomites stand for gray, light-grey and also white bench-bedded, massive and fine-crystalline dolomites, at the base with breccias, limestones and rauwacks, of wide stratigraphical interval (Anisian - Norian), certain relation to Wetterstein dolomites is not clear or proven;

- Raming limestones (Lower Carnian - Cordevolian; 225-229 Ma) represent lateral slope sediments composed of light-coloured organogenic reef limestones;

- Dachstein limestones (Late Carnian; 217-222 $\mathrm{Ma}$ ) are facies from a large platform area, characterised 
by cyclicity ( 300 cycles) of intertidal (dolomitic with laminated algal biostromes), subtidal (rich in typical fossils, especially large megalodontides) and supratidal (shaly, breccious, often reddish) limestone layers;

- Main dolomite ("hauptdolomite"; Tuvalian to Lower Norian; 210-222 Ma) consists of dolomicrite to dolosparites with small contents of siliciclastic (mainly illite and quartz) and organic matter. It is mostly intertidal sediment with alternating layers of algae derived mud and laminated algal stromatolites, sometimes brecciated.

Please note, that this list of lithological types contains only those units, for which sufficiently high population of hydraulically tested boreholes was found. All data were taken from digital geological map of Slovakia in the scale of 1:50,000 (Map server of the State Geological Institute of Dionýz Štúr 2008).

\section{MATERIALS AND METHODS}

A large database of hydrogeological boreholes (wells), containing more than 22,922 wells from all hydrogeological units of the Slovak Republic was developed (Malík et al. 2007). Spatial position of these boreholes is visible on Fig. 1. From these, 16,250 pumping tests could be reinterpreted, using the data stored for each borehole. However, the tested wells were unequally distributed in different aquifers types: 12,963 well-tests in porous aquifers (Quaternary and Neogene sediments), and only 3,287 well-tests were performed in fissure or karst-fissure rock media. In the process of database development, if possible, each borehole was linked to a certain geologi- cal type of pumped aquifer according to screen position (open casing interval), using the digital geological map of Slovakia in the scale of 1:50,000 (Káčer et al. 2005; Map server of the State Geological Institute of Dionýz Štúr 2008). It should be also stressed, that wells with ambiguous position of screen were excluded from further processing to obtain distinct relation of pumping rate to lithological type.

In this paper, hydraulic properties of carbonate rocks (limestones and dolomites) and their comparison to basic well-known hard-rock type (granitoid rocks) are discussed and compared from the point of view of

Tab. 1: Statistics of technical data of boreholes situated in limestone, dolomitic and granitoid aquifers, used for hydraulic data reinterpretation.

\begin{tabular}{|c|c|c|c|c|}
\hline & $\begin{array}{r}\text { boreholes in } \\
\text { dolomites }\end{array}$ & $\begin{array}{r}\text { boreholes in } \\
\text { limestones }\end{array}$ & $\begin{array}{r}\text { boreholes in } \\
\text { granitoids } \\
\end{array}$ & in total \\
\hline & \multicolumn{4}{|c|}{ borehole depth } \\
\hline ranges from - to [m] & $5-2373.5$ & $6-2106$ & $4-1600$ & $4-2373.5$ \\
\hline average $[\mathrm{m}]$ & 150.7 & 164.4 & 90.2 & 147.5 \\
\hline \multirow[t]{2}{*}{ standard deviation [m] } & 284.0 & 256.2 & 202.8 & 267.9 \\
\hline & \multicolumn{4}{|c|}{ borehole diameter } \\
\hline ranges from - to [mm] & $45-2220$ & $45-2020$ & $78-1200$ & $45-2220$ \\
\hline average $[\mathrm{mm}]$ & 353.4 & 279.4 & 418.5 & 336.0 \\
\hline standard deviation [mm] & 232.4 & 193.0 & 221.7 & 223.8 \\
\hline & \multicolumn{4}{|c|}{ average borehole screening interval } \\
\hline ranges from - to (in average ) [m] & $70.2-142.5$ & $37.8-150$ & $32.1-88.5$ & $55.8-137.9$ \\
\hline average total length [m] & 28.0 & 123.8 & 90.1 & 26.9 \\
\hline minimal total length [m] & 0.9 & 5.5 & 3.0 & 0.9 \\
\hline \multirow[t]{2}{*}{ maximal total length [m] } & 543.7 & 1902.8 & 818.0 & 1902.8 \\
\hline & \multicolumn{4}{|c|}{ uncased borehole intervals } \\
\hline number of boreholes with partly uncased walls [-] & 128 & 52 & 21 & 201 \\
\hline average total uncased length [m] & 43.2 & 67.2 & 94.5 & 54.8 \\
\hline minimal total uncased length [m] & 0.1 & 0.5 & 0.2 & 0.1 \\
\hline maximal total uncased length $[\mathrm{m}]$ & 748.5 & 399.5 & 818.0 & 818.0 \\
\hline standard deviation [m] & 99.2 & 93.7 & 210.6 & 114.9 \\
\hline
\end{tabular}


hydraulic properties statistical distribution. Having in mind $49,030 \mathrm{~km}^{2}$ total area of Slovakia itself, the relative density of tested boreholes was 1 well-test per $3.02 \mathrm{~km}^{2}$, while for porous aquifers it was 1 well-test per $3.78 \mathrm{~km}^{2}$ and for hard-rock or karst-fissure aquifer types 1 welltest per $14.92 \mathrm{~km}^{2}$. For dolomites, outcropping on the area of $1,390 \mathrm{~km}^{2}$, data on pumping tests were available from 463 boreholes ( 1 well-test per $3.00 \mathrm{~km}^{2}$ ), while limestones, $\left(238\right.$ boreholes $-934 \mathrm{~km}^{2}-1$ well-test per $3.92 \mathrm{~km}^{2}$ ), and granitoid rocks ( 96 boreholes $-2,000 \mathrm{~km}^{2}$ - 1 well-test per $20.83 \mathrm{~km}^{2}$ ) were more sparsely tested. The spatial position of these basic types of aquifers and the position of wells and boreholes is on Fig. 2.

A brief summary of wells' and boreholes' technical data is listed in the Tab. 1 .

\section{METHODOLOGY OF BOREHOLE TEST REINTERPRETATION}

The vast majority of pumping and recovery tests on wells are performed without recording the data on nearby piezometers, and piezometric levels from only the pumped well are available. Such data can never be directly used in any of equations in which drawdown value $s$ is expressed as a function of distance $\boldsymbol{r}$ from the borehole axis or time value $\boldsymbol{t}$. Although it is practically impossible to assess values of capacity parameters (storativity $S$, specific storativity/yield $\boldsymbol{S}_{s}$ ) without observation boreholes data, still it is possible to estimate resistive hydraulic parameters (e.g., transmissivity $\boldsymbol{T}$, hydraulic conductivity $K$ ). Archive files of common wells, if properly stored (pumping rate, drawdown, well diameter, screen levels, aquifer position), may contain also precious information about the tested aquifer, which can be disclosed by appropriately chosen algorithm. By help of comparative parameters (transmissivity index $\boldsymbol{Y}$, permeability index $\boldsymbol{Z}$ ) which, in general, represent negative logarithmic derivations of $\boldsymbol{T}$ and $\boldsymbol{K}$ values, hydraulic conductivity $K$ and transmissivity $T$ can be estimated. Both $\boldsymbol{Y}$ and $\boldsymbol{Z}$ indexes can be also used in order to show basic classification of permeable environment in classes from 1 to 10 . Such an idea of substitution of physically defined hydraulic parameters by some comparative semi-quantitative parameters is relatively old (e.g., Jetel \& Krásný 1968; Jetel 1989; Šarin 1990).

\section{DEFINITIONS OF PERMEABILITY INDEX Z AND TRANSMISSIVITY INDEX Y}

The comparative parameter of transmissivity, derived from specific capacity of a well, is transmissivity index $\boldsymbol{Y}$ (Jetel \& Krásný 1968), which is derived from specific capacity (at unit drawdown of $1 \mathrm{~m}$, see also the text below) $\boldsymbol{q}^{1}$ using equation (1):

$$
Y=\log \left(10^{6} q^{1}\right)=6+\log q^{1}
$$

The comparative parameter of hydraulic conductivity, derived from specific capacity, is the permeability index $\boldsymbol{Z}$ (Jetel 1964), which is also derived from specific capacity $\boldsymbol{q}^{1}$ using equation (2):

$$
Z=\log 10^{6}\left(q^{1} / M\right)=6+\log \left(q^{1} / M\right)
$$

where:

$M$ - aquifer thickness [m]

$q^{1}$ - standard specific capacity = specific capacity at unit drawdown $\left[\mathrm{L} \cdot \mathrm{s}^{-1} \cdot \mathrm{m}^{-1}\right]$

For better comparison of transmissivity values $T$ and its comparative indexes $\boldsymbol{Y}$, logarithmical transformation of transmissivity $\boldsymbol{Y}_{T}$ - for pumping rate in $\left[\mathrm{L} \cdot \mathrm{s}^{-1}\right]$ can be defined using equation (3). The same can be done for hydraulic conductivity $\boldsymbol{K}$ and permeability index $\boldsymbol{Z}$, resulting in $Z_{K}$ after equation (4):

$$
\begin{aligned}
& Y_{T}=\log T+9 \\
& Z_{K}=\log K+9
\end{aligned}
$$

\section{CALCULATION OF STANDARD SPECIFIC CAPACITY}

For pumping test, which provided only pumping rate and drawdown data on a tested well, comparative parameter values - permeability index $\boldsymbol{Z}$ and transmissivity index $Y$ - are basically derived from specific capacity, a ratio between pumping rate $\boldsymbol{Q}$ and corresponding drawdown $\boldsymbol{s}$ in a well, using equation (5).

$$
q=Q / s
$$

where:

$$
\begin{array}{ll}
\boldsymbol{q} & \text { - specific capacity }\left[\mathrm{L} \cdot \mathrm{s}^{-1} \cdot \mathrm{m}^{-1}\right] \\
\boldsymbol{Q} & \text { - pumping rate }\left[\mathrm{L} \cdot \mathrm{s}^{-1}\right] \\
\boldsymbol{s} & \text { - groundwater table drawdown in a well }[\mathrm{m}]
\end{array}
$$




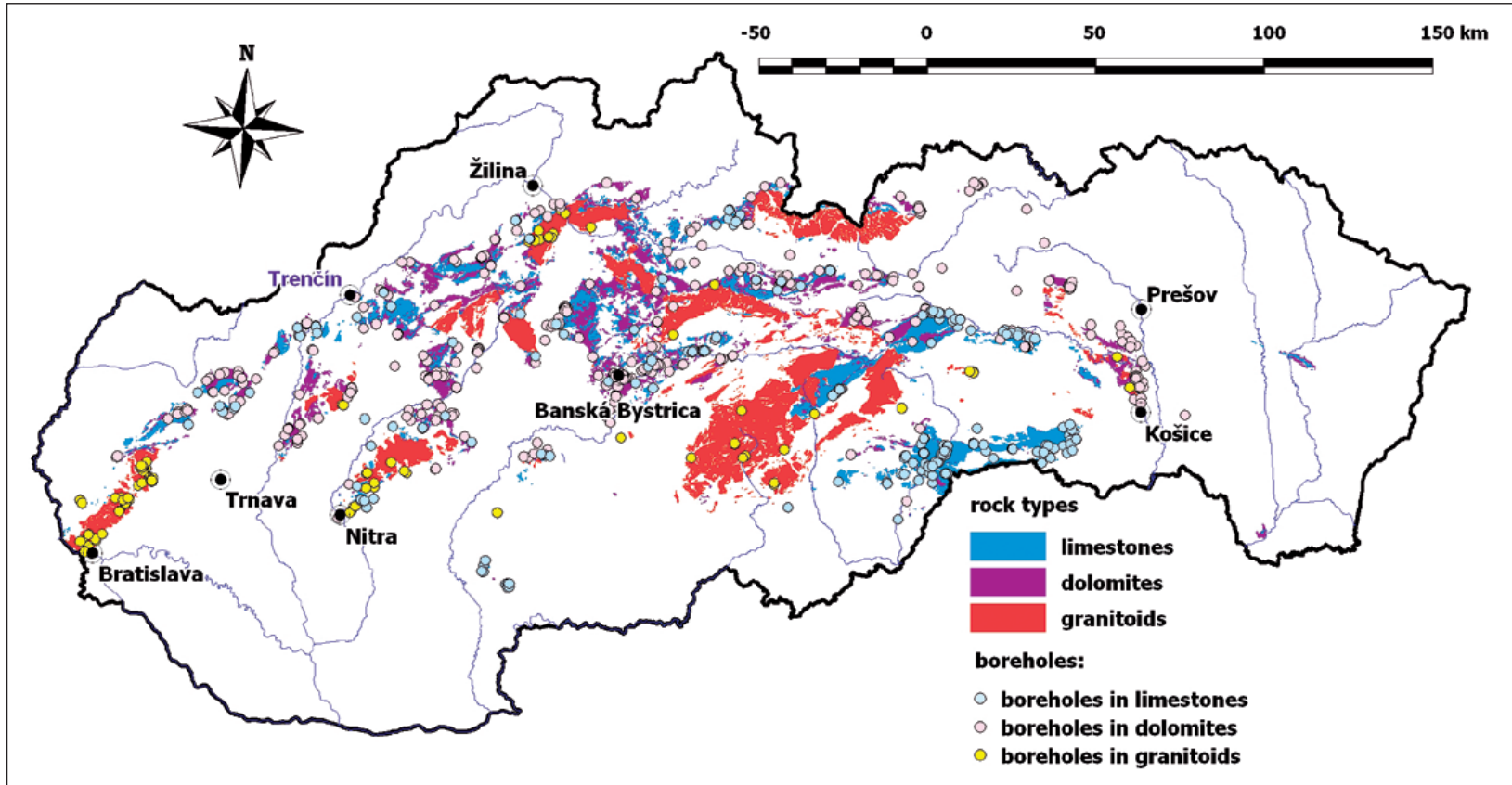

Fig. 2: Spatial distribution of dolomitic, limestone and granitoid aquifers on the Slovak territory.

To derive the representative comparative indexes, pumping rate under the same drawdown conditions is required. With respect to generally nonlinear dependency of $\boldsymbol{Q}$ on $\boldsymbol{s}$, it is recommended to use the unified value of pumping rate - e.g., at the first meter of drawdown (i.e., $\boldsymbol{s}=1 \mathrm{~m}=\boldsymbol{s}^{I}$ ) in the equation (5) if available, or to substitute the measured one (pumped under the real circumstances) by a recalculated value. In this case, unit drawdown specific capacity $\boldsymbol{q}^{1}=$ "standard specific capacity" as defined by Jetel $(1985,1995 a)$, stands for specific capacity. When measured drawdown values $\boldsymbol{s}^{n}$ differ from $1 \mathrm{~m}$, in the case of thick $(\boldsymbol{M}>10 \mathrm{~m})$ unconfined aquifer, specific capacity at unit drawdown will be calculated with equation (6):

$$
q^{1}=q^{\mathrm{n}} \cdot(2 \cdot M-1) /\left(2 \cdot M-s^{\mathrm{n}}\right)
$$

where:

$\boldsymbol{q}^{1}$ - standard specific capacity $=$ specific capacity at unit drawdown $\left[\mathrm{L} \cdot \mathrm{s}^{-1} \cdot \mathrm{m}^{-1}\right]$

$s^{n}$ - unconfined groundwater table drawdown, measured in a well $[\mathrm{m}]$

$M$ - original thickness of an unconfined aquifer unaffected by pumping $[\mathrm{m}]$

$\boldsymbol{q}^{n}$ - specific capacity at drawdown $\boldsymbol{s}^{n}\left[\mathrm{~L} \cdot \mathrm{s}^{-1} \cdot \mathrm{m}^{-1}\right]$

If, while performing unconfined aquifer test, the drawdown exceeds value more than $1 / 10$ of the original aquifer thickness $\boldsymbol{M}$, the measured drawdown should be adjusted after equation (7) (Jacob 1944 in Jetel 1985) and an adjusted drawdown $\boldsymbol{s}_{\boldsymbol{c}}(8)$ should be used instead of measured drawdown $s$ in specific capacity calculations. Such an adjustment is necessary due to significant reduction of the groundwater flow cross-sectional area and subsequent decrease of transmissivity.

$$
s_{c}=s^{n}-s^{2} /(2 \cdot M)
$$

where:

$$
\begin{gathered}
\boldsymbol{s}_{\boldsymbol{c}} \quad \text { - adjusted unconfined groundwater table draw- } \\
\text { down in a well [m] }
\end{gathered}
$$

$$
\mathbf{q}^{1}=\mathbf{Q} / \mathbf{s}_{\mathbf{c}}
$$

In the case when standard specific discharge calculation was performed without drawdown adjustment $\left(\boldsymbol{s}\right.$ to $\left.\boldsymbol{s}_{\boldsymbol{c}}\right)$, in spite of the fact that the drawdown in the well exceeded $1 / 10$ of the unaffected unconfined aquifer thickness, according to equation (7) the value of the adjusted standard specific discharge $\boldsymbol{q}_{c}{ }^{1}$ should be used to calculate values of approximate logarithmical parameters $\boldsymbol{Y}$ and $\boldsymbol{Z}$. Value of $\boldsymbol{q}_{c}{ }^{1}$ is obtained by the use of equation (9):

$$
\boldsymbol{q}_{c}{ }^{1}=\boldsymbol{q}^{1} \cdot(2 \cdot M) /(2 \cdot M-1)
$$

where:

$\boldsymbol{q}_{c}{ }^{1}$ - adjusted standard specific capacity $\left[\mathrm{L} \cdot \mathrm{s}^{-1} \cdot \mathrm{m}^{-1}\right]$ 
In the process of permeability index $\boldsymbol{Z}$ calculation (equation (2)), instead of drawdown adjustment or using adjusted standard specific capacity, also value of adjusted aquifer thickness $\boldsymbol{M c}$ derived from original thickness $\boldsymbol{M}$, can be used. For calculation of adjusted aquifer thickness $\boldsymbol{M c}$, equation (10) can be employed. One can use the $\boldsymbol{M c}$ value in equation (2), but in the same time, an unadjusted value of specific capacity $\boldsymbol{q}^{n}$ should be used.

$M c=M-s^{n} / 2$

where:

$\boldsymbol{M c}$ - adjusted thickness of an unconfined aquifer [m]

Under confined aquifer conditions, the dependency of pumping rate $\boldsymbol{Q}$ from drawdown $\boldsymbol{s}$ is less or more linear up to a certain threshold value of $\boldsymbol{s}$. For bigger piezometric depressions, however, this relation becomes nonlinear. If sufficient number of pairs of $Q$ and $s$ values are available for identification of $\boldsymbol{Q}=\mathrm{f}(\boldsymbol{s})$ curve, the standard specific capacity can be derived graphically by interpolation or extrapolation to $s=1 \mathrm{~m}$ value. Without this possibility, an estimation of standard specific capacity can be performed using relation shown in equation (6) in parabolic approximation of the curve (equation (11)):

$q^{1}=q^{n} \cdot(2 \cdot H-1) /\left(2 \cdot H-s^{n}\right)$

where:

$\boldsymbol{H}$ - distance between the static water level in a well and lowest part of the open well casing [m]

Aforementioned algorithms serve for data unification from different wells with different drawdowns and pumping rates. Even though such procedure is only a rough approximation of an unknown nonlinear curve $Q=\mathrm{f}(\boldsymbol{s})$, it allows objectively reproducible correction of the specific capacity decrease with drawdown to achieve data comparability. In our dataset of 797 boreholes, average value of transmissivity index $\boldsymbol{Y}$ was 5.57, with median of 5.60 and standard deviation 0.97. Upper and lower $10 \%$ percentile values were within the interval of $<$ 4.30; $6.81>$, while minimum $\boldsymbol{Y}$ values of 1.92 and maximum of 8.57 were found. The permeability index, $Z$, had reached the values from -0.13 to 6.99 with average 3.91 , median 3.92 and standard deviation of 1.10 .

\section{PRINCIPLE OF LOGARITHMIC CONVERSION DIFFERENCE}

Because the comparative parameters $\boldsymbol{Z}$ and $\boldsymbol{Y}$ represent individual functions of specific capacity $\boldsymbol{q}$ values, the es- timation of hydraulic parameters of rocks from approximate (comparative) parameters originates from the existence of the relation between transmissivity coefficient $\boldsymbol{T}$ and specific capacity $\boldsymbol{q}$, which is, for our purpose, expressed in a form of a logarithmic conversion difference, defined by Jetel (1985) in equation (12):

$$
\begin{aligned}
& d=\log T-\log q \\
& \text { i.e., } \\
& T / q=10^{d}
\end{aligned}
$$

where $\boldsymbol{T}$ and $\boldsymbol{q}$ are expressed in $\left[\mathrm{m}^{2} \cdot \mathrm{s}^{-1}\right]$. From comparison of (12) and (13) it is clear, that the relation between transmissivity coefficient $\boldsymbol{T}$ and transmissivity index $\boldsymbol{Y}$ as a transformation of specific capacity $\boldsymbol{q}$ can be expressed by equation (14):

$$
T=\operatorname{antilog}(Y+d-9)=10^{(Y+d-9)}
$$

The same applies for the relation of hydraulic conductivity $\boldsymbol{K}$ to permeability index $\boldsymbol{Z}$, where:

$$
K=\operatorname{antilog}(Z+d-9)=10^{(Z+d-9)}
$$

$$
\begin{aligned}
& \text { where: } \\
& \begin{array}{l}
\boldsymbol{T} \text { - aquifer transmissivity }\left[\mathrm{m}^{2} \cdot \mathrm{s}^{-1}\right] \\
\boldsymbol{K} \text { - aquifer hydraulic conductivity }\left[\mathrm{m} \cdot \mathrm{s}^{-1}\right] .
\end{array}
\end{aligned}
$$

Logarithmic implication of equations (12) and (13) is the expression of logarithmic conversion difference as a difference between values $\boldsymbol{Y}_{T}$ and $\boldsymbol{Y}$, after introduction of transformation of $\boldsymbol{Y}_{T}$ defined by equation (3), i.e., as:

$$
d=Y_{T}-Y
$$

By introducing the conversion difference, the whole problem of estimation of hydraulic conductivity $\boldsymbol{K}$ from transmissivity index $\boldsymbol{Y}$ is simplified into a problem of optimal estimation of the corresponding conversion difference $\boldsymbol{d}$. The conversion difference consists of primary conversion difference $\boldsymbol{d}_{\boldsymbol{0}}$, and additional difference $\boldsymbol{d}_{\boldsymbol{d}}$ (17):

$$
d=d_{0}+d_{d}
$$

In other words, logarithmic conversion difference $\boldsymbol{d}$ contains the key for calculation of hydraulic parameters from simple specific capacity value, as by the use of equations (14) and (1), if $\mathrm{Q} / \mathrm{s}$ is the standard specific capacity, e.g., transmissivity equals to $10^{d-3-\log (\mathrm{Q} / \mathrm{s})}$. 


\section{ESTIMATION OF CONDUCTIVITY (RESISTIVE) HYDRAULIC PARAMETERS BY USE OF CONVERSION DIFFERENCE}

\section{Primary conversion difference}

The basic constituent of the total conversion difference $d$ in equations (14) and (15) is a part expressing the difference between $\log T$ and $\log q$ for given calculation conditions, assuming a hydrodynamically perfect well - i.e., a well, of which radius $\boldsymbol{r}_{v}$ equals the effective (equivalent) radius $\boldsymbol{r}_{e v}$. By other words, we assume a well without additional hydraulic resistance of flow into the well and inside the well towards the well head. This component, i.e., the ideal value of the conversion difference $\boldsymbol{d}$ for hydrodynamically perfect well, is denoted as primary conversion difference $\boldsymbol{d}_{\mathbf{0}}$ (dimensionless). For the conditions of validity of the Dupuit-Theim equation of steady radial flow to a hydrodynamically perfect well (in Jetel 1982), it is expressed by equation (18):

$$
d_{0}=\log \left[\log \left(r_{d} / r_{v}\right)\right]-0,436
$$

where:

$\boldsymbol{r}_{\boldsymbol{d}}$ - calculated depression cone radius (Jetel 1982) [m]

$r_{v}-$ well radius $[\mathrm{m}]$

For the quasi steady-state phase of transient flow under assumption of Jacob logarithmic approximation of Theis well function (Jacob 1946) it is expressed by equation (19) by Jetel (1985):

$$
d_{0}=\log \left(0,183 \cdot \log \left(2,25 \cdot a \cdot t / r_{v}\right)\right)
$$

where:

$\boldsymbol{d}_{0}$ - primary conversion difference [-]

$t$ - time from the beginning of a pumping test, determining the current extent of depression cone [s]

$\boldsymbol{a}$ - hydraulic diffusivity coefficient (ratio between transmissivity $\boldsymbol{T}$ and water-table storativity $S$ or elastic storativity $S_{P} ; \boldsymbol{a}=\boldsymbol{T} / \boldsymbol{S}$ )

In case of hydrodynamically perfect well, primary conversion difference equals total conversion difference. As a preliminary estimate of transmissivity $\boldsymbol{T}$, a value of $\boldsymbol{T}_{Y}$, expressed from measured value of index $\boldsymbol{Y}$ after equation (3), can be used, and then the first preliminary estimate $\boldsymbol{T}_{Y}=$ antilog $(\boldsymbol{Y}-9)$. Values of primary conversion difference use to range from -0.3 to 0.3 , but values $<-0.5$ or $>0.5$ show "unusual behaviour" of interpreted data, where inspection of input parameters is required
(Jetel 1985). In our dataset (797 interpreted boreholes), average value of primary conversion difference was 0.01 , median was 0.15 and standard deviation 0.36 . Upper and lower $10 \%$ percentile of our dataset was within the interval of $<-0.43 ; 0.29>$.

\section{Additional conversion difference}

The additional conversion difference $\boldsymbol{d}_{\boldsymbol{d}}$ consists of partial differences, each of them expressing effect of linear or nonlinear flow resistivities in a real well:

$$
d_{d}=d_{S}+d_{L}+d_{C}+d_{H}+d_{X}
$$

Additional conversion differences (dimensionless), reflecting the effect of additional linear resistivities, can be separated into skin-effect difference $\boldsymbol{d}_{\boldsymbol{s}}$ and partialpenetration difference $\boldsymbol{d}_{\boldsymbol{L}}$.

The skin-effect difference reflects flow resistance originating from well clogging or deterioration of the natural aquifer structure in the near-well zone, and resistance caused by reduction of the active surface of a borehole wall as a result of covering by filter, perforation, etc. It is practically impossible to determine this analytically, and in further calculations $\boldsymbol{d}_{\boldsymbol{s}}$ is usually neglected or roughly estimated by analogy (Jetel 1995b).

The partial-penetration difference $\boldsymbol{d}_{\boldsymbol{L}}$ represents resistance caused by incomplete penetration of aquifer thickness by well screen. It is expressed as a ratio between theoretical specific capacity of hydrodynamically perfect well $\boldsymbol{q}_{M}$ and specific capacity of hydrodynamically imperfect well $\boldsymbol{q}_{L}$ :

$$
d_{L}=\log q_{M} / q_{L}
$$

More detailed procedures for $\boldsymbol{d}_{L}$ determination were published by Jetel (1985). The difference cannot be calculated unless the thickness $\boldsymbol{M}$ is known. Such situation may occur mainly in fissured unstratified aquifers.

Additional differences, reflecting nonlinear resistances, can be divided into turbulence difference $\boldsymbol{d}_{C^{\prime}}$ expressing the effect of quadratic nonlinear resistance (especially turbulence of flow inside the well), and difference $\boldsymbol{d}_{X}$, comprising effects of all remaining nonlinear resistances.

The quadratic turbulence difference is significant only when huge amounts of water (tens or hundreds of litres per second) are pumped. It rises with pumping rate, and decreases with the enlargement of well radius or with increasing transmissivity. It can be estimated by use of the equation (Jetel 1985):

$$
d_{C}=\log \left[\left(\operatorname{antilog} d_{0}+Q / r T^{0,25}\right) /\left(\operatorname{antilog} d_{0}\right)\right]
$$


Outseepage interval difference $\boldsymbol{d}_{H}$ is generally neglected, because it is disputable by itself. Despite unquestionable existence of an outseepage interval of an unconfined water table, Busch and Luckner (1972) presented arguments, which put in doubt its practical reason and its effect on additional drawdown in a well (Jetel 1985).

Unknown difference $\boldsymbol{d}_{X}$ is a difference, which cannot be clearly determined, but together with the skin-effect difference are included in the residual difference $\boldsymbol{d}_{Z}$, essential for the precise determination of the total conversion difference:

$$
d_{z}=d_{s}+d_{X}
$$

Total conversion difference is therefore expressed as a sum of estimated differences $\boldsymbol{d}_{\boldsymbol{0}}, \boldsymbol{d}_{\boldsymbol{L}}$ and $\boldsymbol{d}_{\boldsymbol{c}}$, and an unknown residual difference.

$$
d_{z}=d-d_{0}-d_{L}-d_{c}=d_{s}+d_{x}
$$

The residual difference $\boldsymbol{d}_{z}$ is usually composed solely by skin-effect difference $\boldsymbol{d}_{s}$. During a preliminary estimate can be neglected, what means that:

$$
d=d_{0}+d_{L}+d_{C}
$$

In the dataset of 797 interpreted boreholes, average values of partial-penetration difference $\boldsymbol{d}_{L}$, quadratic turbulence difference $\boldsymbol{d}_{C}$, and outseepage interval difference $\boldsymbol{d}_{H}$ were $0.34,0.41$ and 0.61 , respectively, and their median values were of $0.30,0.32$ and 0.56 . Calculation of outseepage interval difference $\boldsymbol{d}_{H}$ was applied only in 217 cases. Standard deviations values were $0.23,0.26$ and 0.51 ; upper and lower $10 \%$ percentiles were of $<0.15$; $0.64>,<0.14 ; 0.84>$ and $<0.18 ; 1.42>$. Based on primary and additional conversion differences, the set of final conversion differences $\boldsymbol{d}$ was prepared: the values there were ranging from -1.16 to 2.29 , with median value of 0.22 and average of 0.25 . The interval of upper and lower $10 \%$ percentiles was $\langle-0.13 ; 0.68>$.

Using standard specific capacity $\boldsymbol{q}^{1}$ and logarithmic conversion difference $\boldsymbol{d}$, obtained for each well or borehole, datasets of $\boldsymbol{T}$ and $\boldsymbol{K}$ values were developed. Some authors tried to estimate "regional values" of the logarithmic conversion difference for certain rock types (Olekšák 2004; Helma 2007). Other studies correlated values of conversion difference with transmissivity derived by standard interpretation of pumping tests, using equations (12) or (16) - e.g., Jetel (1994) or Helma (2005). In this study, only conversion difference values individually calculated for each borehole were used.

\section{RESULTS AND DISCUSSION FOR DOLOMITIC, LIMESTONE AND GRANITOID ROCKS AQUIFERS}

Equations (14) and (15) from the previous chapter, as well as using logarithmical conversion differences (equations (16) to (25)), based on archived borehole data and calculated separately for every borehole, enabled us to calculate values of transmissivity $\boldsymbol{T}$ and hydraulic conductivity $\boldsymbol{K}$ for every borehole. Statistical distribution of these values was tested as lognormal. The lognormal distribution was confirmed by Kolmogorov-Smirnov test with Lilliefors significance correction applied, and Sha-
piro-Wilk test (see Tab. 2). Since t-test assumes normal distribution, data were first log-transformed prior to normality testing.

Together 238 well tests were available for limestones, 463 for dolomites and 96 for granitoid rocks (Tab. 3). For the results of re-interpreted well-tests, the probability plots (cumulated relative frequencies plots) and relative frequency histograms of $\log K$ and $\log T$ are shown on Figs. 3 and 4. Relative frequencies plot-

Tab. 2: Results of normality testing of the hydraulic parameters. K-S Kolmogorov-Smirnov test statistics; S-W Shapiro-Wilk test statistics; Sig. observed significance level (often called the p-value).

\begin{tabular}{|l|l|c|c|c|c|}
\hline Parameter & Rock & K-S & Sig. & S-W & Sig. \\
\hline \multirow{3}{*}{$\begin{array}{l}\text { Hydraulic } \\
\text { conductivity }\end{array}$} & Dolomites & 0.056 & 0.002 & 0.989 & 0.002 \\
\cline { 2 - 6 } & Limestones & 0.041 & 0.2 & 0.984 & 0.01 \\
\cline { 2 - 6 } & Granites & 0.061 & 0.2 & 0.983 & 0.265 \\
\hline \multirow{4}{*}{ Transmissivity } & Dolomites & 0.041 & 0.066 & 0.992 & 0.015 \\
\cline { 2 - 6 } & Limestones & 0.061 & 0.032 & 0.982 & 0.004 \\
\cline { 2 - 6 } & Granites & 0.078 & 0.177 & 0.978 & 0.115 \\
\hline
\end{tabular}




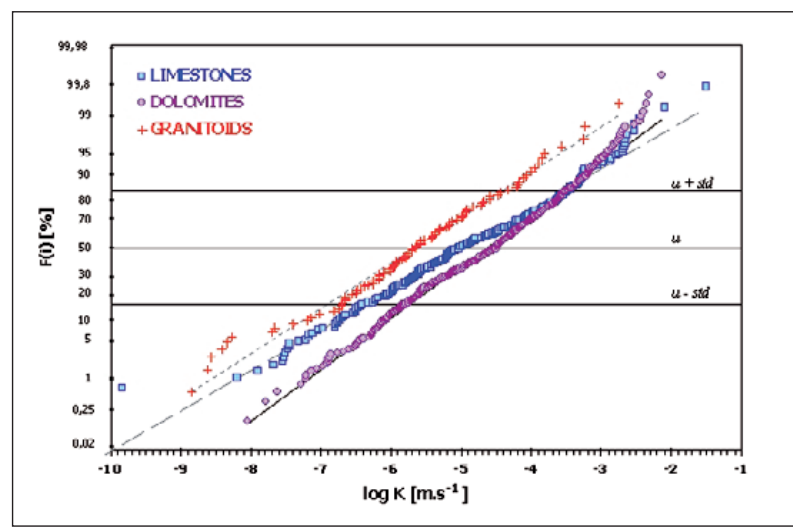

ted on Fig. 4 are understood as number of pumping test results within certain interval, compared to the total number of pumping tests. The steeper slope for dolo-
Fig. 3: Probability plot of logarithmically transformed hydraulic conductivity values for boreholes situated in limestone, dolomitic and granitoid aquifers on the Slovak territory.

mites on Fig. 3 reveals more homogeneous distribution of hydraulic conductivity (standard deviation $\sigma$ of $\log K$ values 1.09), while for granitoids $(\sigma=1.25)$ and limestones (1.39) the heterogeneity increases. Probability plots and relative frequency histograms of transmis-

Tab. 3: Statistics on transmissivity and hydraulic conductivity values for boreholes situated in limestone, dolomitic and granitoid aquifers.

\begin{tabular}{|c|c|c|c|}
\hline & all types of dolomites & all types of limestones & all granitoid rocks \\
\hline & \multicolumn{3}{|c|}{$k\left[m \cdot s^{-1}\right]$} \\
\hline geometrical mean- $X$ & $2.35 \cdot 10^{-5}$ & $1.06 \cdot 10^{-5}$ & $2.15 \cdot 10^{-6}$ \\
\hline $\mathrm{X}+\sigma$ & $2.90 \cdot 10^{-4}$ & $2.64 \cdot 10^{-4}$ & $3.80 \cdot 10^{-5}$ \\
\hline $\max$ & $7.36 \cdot 10^{-3}$ & $3.13 \cdot 10^{-2}$ & $1.81 \cdot 10^{-3}$ \\
\hline $\min$ & $9.14 \cdot 10^{-9}$ & $5.51 \cdot 10^{-11}$ & $1.40 \cdot 10^{-9}$ \\
\hline$X-\sigma$ & $1.90 \cdot 10^{-6}$ & $4.29 \cdot 10^{-7}$ & $1.22 \cdot 10^{-7}$ \\
\hline $\log \mathrm{K}$ standard deviation $\sigma$ & 1.09 & 1.39 & 1.25 \\
\hline \multirow[t]{2}{*}{ median } & $3.21 \cdot 10^{-5}$ & $9.45 \cdot 10^{-6}$ & $2.10 \cdot 10^{-6}$ \\
\hline & \multicolumn{3}{|c|}{$T\left[m^{2} \cdot s^{-1}\right]$} \\
\hline geometrical mean- $X$ & $1.04 \cdot 10^{-3}$ & $6.16 \cdot 10^{-4}$ & $6.51 \cdot 10^{-5}$ \\
\hline $\mathrm{X}+\sigma$ & $1.04 \cdot 10^{-2}$ & $1.24 \cdot 10^{-2}$ & $6.02 \cdot 10^{-4}$ \\
\hline $\max$ & $3.00 \cdot 10^{-1}$ & $1.19 \cdot 10^{\circ}$ & $1.56 \cdot 10^{-2}$ \\
\hline $\min$ & $9.83 \cdot 10^{-7}$ & $6.12 \cdot 10^{-9}$ & $1.21 \cdot 10^{-7}$ \\
\hline $\mathrm{X}-\sigma$ & $1.04 \cdot 10^{-4}$ & $3.05 \cdot 10^{-5}$ & $7.04 \cdot 10^{-6}$ \\
\hline $\log T$ standard deviation $\sigma$ & 1.00 & 1.30 & 0.97 \\
\hline median & $1.20 \cdot 10^{-3}$ & $7.58 \cdot 10^{-4}$ & $7.54 \cdot 10^{-5}$ \\
\hline number of evaluated wells & 463 & 238 & 96 \\
\hline
\end{tabular}

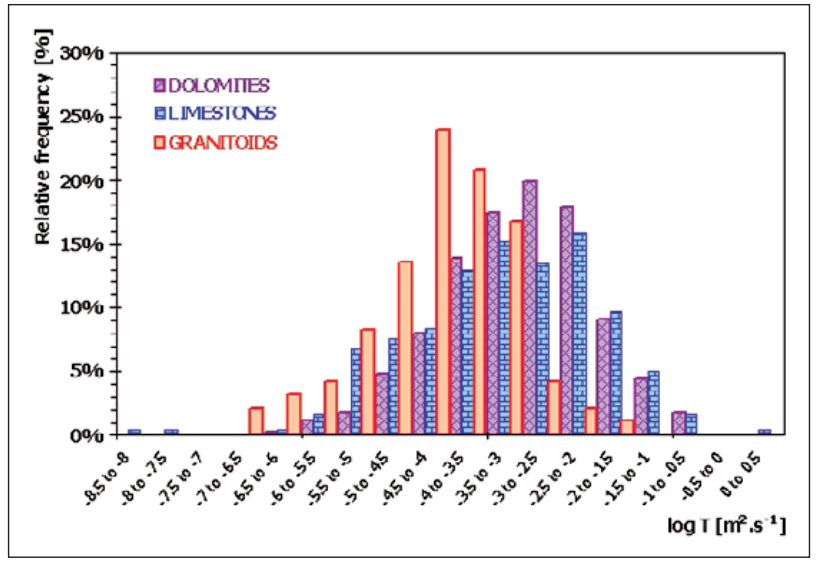

sivity and hydraulic conductivity values have similar shape, as demonstrated in Tab. 3.

Comparing geometrical means of transmissivity $(T)$ and hydraulic conductivity $(K)$ for different aquifer types, low transmissivity for granitoids $\left(6.51 \cdot 10^{-5} \mathrm{~m}^{2} \cdot \mathrm{s}^{-}\right.$ $\left.{ }^{1}\right)$, and one order of magnitude higher for limestones

Fig. 4: Relative frequency histograms of transmissivity logarithms $(\log T)$ values for boreholes situated in limestone, dolomitic and granitoid aquifers on the Slovak territory. 
is evident $\left(6.16 \cdot 10^{-4} \mathrm{~m}^{2} \cdot \mathrm{s}^{-1}\right.$; Tab. 3 and Fig. 3), probably due to fracture aperture enhancement by karstification / dissolution. The highest geometrical mean of transmissivity values was found for dolomites $\left(1.04 \cdot 10^{-3} \mathrm{~m}^{2} \cdot \mathrm{s}^{-1}\right)$. The same comparison made for hydraulic conductivity geometrical means shows the lowest $\boldsymbol{K}$ values for grani-
For closer look, several dolomite and limestone lithological types were studied when the number of pumping test results was sufficient to enable at least basic statistical comparisons. The results are listed in Tabs. 4 to 6, and shown on Figs. 5 and 6. For dolomitic aquifers, analyses of Wetterstein, Ramsau dolomites, "grey"
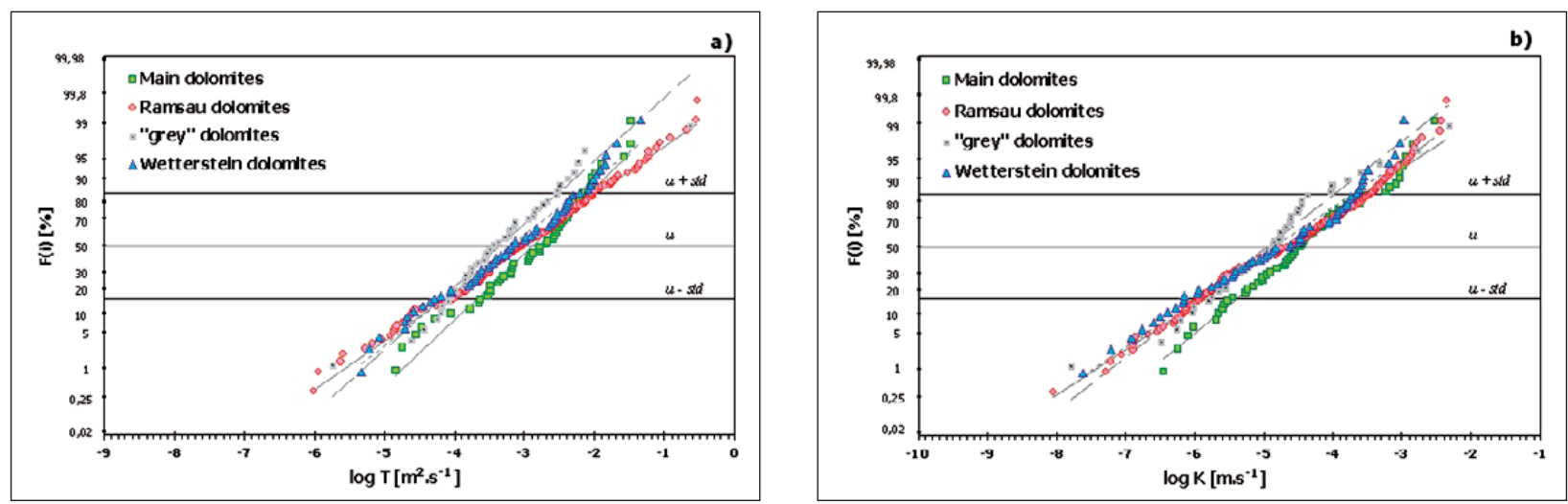

Fig. 5: Probability plots of a) logarithmically transformed transmissivity $(\log T)$ and b) hydraulic conductivity (log K) values for boreholes situated in different types of limestones.
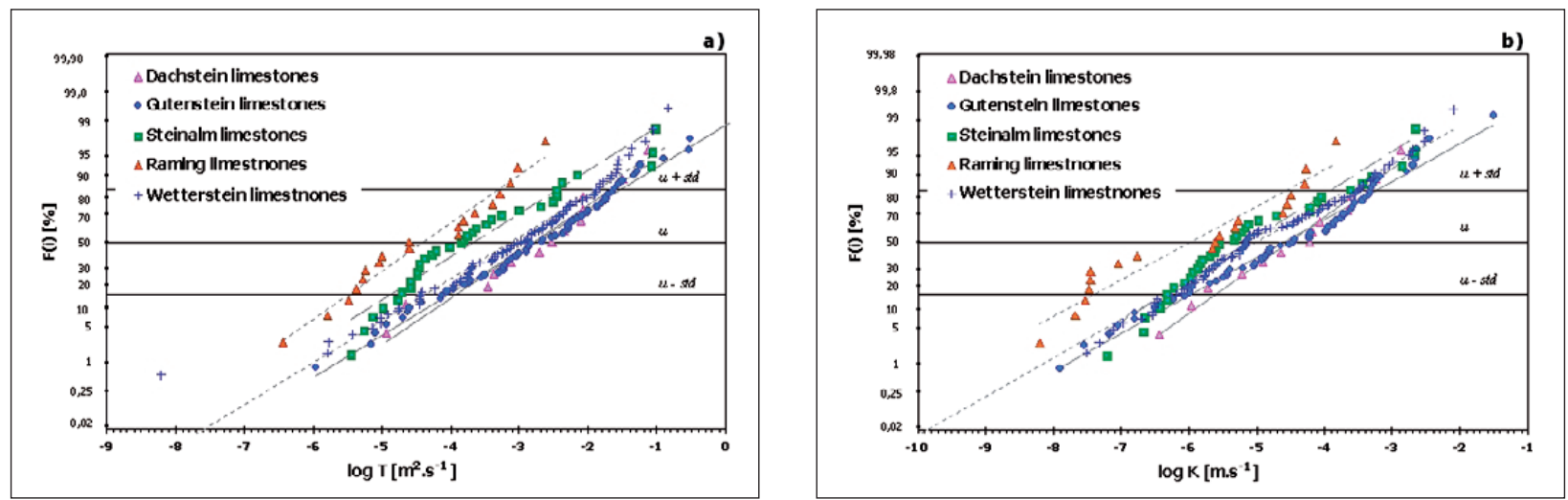

Fig. 6: Probability plots of a) logarithmically transformed transmissivity $(\log T)$ and b) hydraulic conductivity (log K) values for boreholes situated in different types of dolomites.

toids $\left(2.15 \cdot 10^{-6} \mathrm{~m} \cdot \mathrm{s}^{-1}\right)$, one order of magnitude higher for limestones $\left(1.06 \cdot 10^{-5} \mathrm{~m} \cdot \mathrm{s}^{-1}\right)$, and the highest for dolomite aquifers $\left(2.35 \cdot 10^{-5} \mathrm{~m} \cdot \mathrm{s}^{-1}\right)$.

The median values listed in the Tab. 3 follow the same structure both for the transmissivity (granitoids $7.54 \cdot 10^{-5}$ - limestones $7.58 \cdot 10^{-4}$ - dolomites $1.20 \cdot 10^{-3} \mathrm{~m}^{2} \cdot \mathrm{s}^{-1}$ ) and

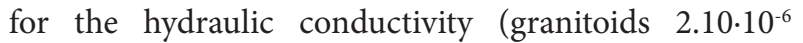
- limestones $9.54 \cdot 10^{-6}$ - dolomites $\left.3.21 \cdot 10^{-5} \mathrm{~m} \cdot \mathrm{s}^{-1}\right)$. The median value of $1.20 \cdot 10^{-3} \mathrm{~m}^{2} \cdot \mathrm{s}^{-1}$ for dolomites is higher in comparison to median value of $4.35 \cdot 10^{-4} \mathrm{~m}^{2} \cdot \mathrm{s}^{-1}$, reported for dolomites by Verbovšek and Veselič (2008). We should note that the all analysed dolomitic aquifers from Slovakia are of Middle/Upper Triassic age, diagenetically consolidated to rigid masses and afterwards tectonically disrupted into densely fissured aquifers. dolomites and "hauptdolomites" - Main dolomites had proven that neither one type predominates in transmissivity (Fig. 6a, Tab. 4). Main dolomites were traditionally supposed to be less permeable (drilling companies' reports), but it seems this tradition had arisen from some local or regional problems. Limestones were analysed for Gutenstein, Steinalm, Wetterstein, Raming and Dachstein limestones. Lowered hydraulic properties in comparison to the bulk values were found for Steinalm and especially for Raming limestones (Figs. 5a, 5b and Tab. 5): the $\boldsymbol{T}$ bulk value median was $7.58 \cdot 10^{-4} \mathrm{~m}^{2} \cdot \mathrm{s}^{-1}$, while $2.47 \cdot 10^{-5} \mathrm{~m}^{2} \cdot \mathrm{s}^{-1}$ for Raming and $1.47 \cdot 10^{-4} \mathrm{~m}^{2} \cdot \mathrm{s}^{-1}$ for Steinalm limestones. The heterogeneity of all datasets is relatively the same and considerably big (standard deviation $\sigma$ of $\log T$ values in Tab. 5). 
PETER MALÍK \& JAROMÍR ŠVASTA

Tab. 4: Statistics of transmissivity and hydraulic conductivity values for boreholes situated in selected types of dolomitic aquifers.

\begin{tabular}{|c|c|c|c|c|c|}
\hline & $\begin{array}{l}\text { all types of } \\
\text { dolomites }\end{array}$ & $\begin{array}{c}\text { Main } \\
\text { dolomites }\end{array}$ & $\begin{array}{c}\text { Ramsau } \\
\text { dolomites }\end{array}$ & $\begin{array}{c}\text { Grey } \\
\text { dolomites }\end{array}$ & $\begin{array}{c}\text { Wetterstein } \\
\text { dolomites }\end{array}$ \\
\hline & \multicolumn{5}{|c|}{$\mathbf{k}\left[\mathrm{m} \cdot \mathrm{s}^{-1}\right]$} \\
\hline geometrical mean-X & $2.35 \cdot 10^{-5}$ & $3,50 \cdot 10^{-5}$ & $1,93 \cdot 10^{-5}$ & $1,13 \cdot 10^{-5}$ & $1,43 \cdot 10^{-5}$ \\
\hline $\mathrm{X}+\sigma$ & $2.90 \cdot 10^{-4}$ & $2,99 \cdot 10^{-4}$ & $2,77 \cdot 10^{-4}$ & $1,06 \cdot 10^{-4}$ & $1,94 \cdot 10^{-4}$ \\
\hline $\max$ & $7.36 \cdot 10^{-3}$ & $3,02 \cdot 10^{-3}$ & $4,43 \cdot 10^{-3}$ & $4,74 \cdot 10^{-3}$ & $1,05 \cdot 10^{-3}$ \\
\hline $\min$ & $9.14 \cdot 10^{-9}$ & $3,58 \cdot 10^{-7}$ & $9,14 \cdot 10^{-9}$ & $1,60 \cdot 10^{-8}$ & $2,43 \cdot 10^{-8}$ \\
\hline$X-\sigma$ & $1.90 \cdot 10^{-6}$ & $4,11 \cdot 10^{-6}$ & $1,35 \cdot 10^{-6}$ & $1,20 \cdot 10^{-6}$ & $1,05 \cdot 10^{-6}$ \\
\hline log K standard deviation $\sigma$ & 1.09 & 0.93 & 1.16 & 0.97 & 1.13 \\
\hline \multirow[t]{2}{*}{ median } & $3.21 \cdot 10^{-5}$ & $3,41 \cdot 10^{-5}$ & $2,51 \cdot 10^{-5}$ & $1,22 \cdot 10^{-5}$ & $2,35 \cdot 10^{-5}$ \\
\hline & \multicolumn{5}{|c|}{$\mathrm{T}\left[\mathrm{m}^{2} \cdot \mathrm{s}^{-1}\right]$} \\
\hline geometrical mean-X & $1.04 \cdot 10^{-3}$ & $1,32 \cdot 10^{-3}$ & $9,06 \cdot 10^{-4}$ & $4,41 \cdot 10^{-4}$ & $6,37 \cdot 10^{-4}$ \\
\hline $\mathrm{X}+\sigma$ & $1.04 \cdot 10^{-2}$ & $8,16 \cdot 10^{-3}$ & $1,09 \cdot 10^{-2}$ & $3,00 \cdot 10^{-3}$ & $5,63 \cdot 10^{-3}$ \\
\hline $\max$ & $3.00 \cdot 10^{-1}$ & $3,27 \cdot 10^{-2}$ & $3,00 \cdot 10^{-1}$ & $2,26 \cdot 10^{-1}$ & $4,51 \cdot 10^{-2}$ \\
\hline $\min$ & $9.83 \cdot 10^{-7}$ & $1,47 \cdot 10^{-5}$ & $9,83 \cdot 10^{-7}$ & $1,86 \cdot 10^{-6}$ & $4,62 \cdot 10^{-6}$ \\
\hline$X-\sigma$ & $1.04 \cdot 10^{-4}$ & $2,15 \cdot 10^{-4}$ & $7,52 \cdot 10^{-5}$ & $6,49 \cdot 10^{-5}$ & $7,21 \cdot 10^{-5}$ \\
\hline $\log T$ standard deviation $\sigma$ & 1.00 & 0,79 & 1,08 & 0,83 & 0,95 \\
\hline median & $1.20 \cdot 10^{-3}$ & $1,84 \cdot 10^{-3}$ & $9,16 \cdot 10^{-4}$ & $3,60 \cdot 10^{-4}$ & $6,50 \cdot 10^{-4}$ \\
\hline number of evaluated wells & 463 & 56 & 178 & 44 & 61 \\
\hline
\end{tabular}

Tab. 5: Statistics of transmissivity and hydraulic conductivity values for boreholes situated in selected types of limestone aquifers.

\begin{tabular}{|c|c|c|c|c|c|c|}
\hline & $\begin{array}{l}\text { all types of } \\
\text { limestones }\end{array}$ & $\begin{array}{l}\text { Dachstein } \\
\text { limestones }\end{array}$ & $\begin{array}{l}\text { Gutenstein } \\
\text { limestones }\end{array}$ & $\begin{array}{c}\text { Steinalm } \\
\text { limestones }\end{array}$ & $\begin{array}{c}\text { Raming } \\
\text { limestones }\end{array}$ & $\begin{array}{l}\text { Wetterstein } \\
\text { limestones }\end{array}$ \\
\hline & \multicolumn{6}{|c|}{$\mathrm{k}\left[\mathrm{m} \cdot \mathrm{s}^{-1}\right]$} \\
\hline geometrical mean-X & $1.06 \cdot 10^{-5}$ & $3,04 \cdot 10^{-5}$ & $2,53 \cdot 10^{-5}$ & $7,23 \cdot 10^{-6}$ & $1,13 \cdot 10^{-6}$ & $1,02 \cdot 10^{-5}$ \\
\hline$X+\sigma$ & $2.64 \cdot 10^{-4}$ & $3,68 \cdot 10^{-4}$ & $6,01 \cdot 10^{-4}$ & $1,21 \cdot 10^{-4}$ & $2,96 \cdot 10^{-5}$ & $2,30 \cdot 10^{-4}$ \\
\hline $\max$ & $3.13 \cdot 10^{-2}$ & $1,35 \cdot 10^{-3}$ & $3,13 \cdot 10^{-2}$ & $2,26 \cdot 10^{-3}$ & $1,49 \cdot 10^{-4}$ & $8,07 \cdot 10^{-3}$ \\
\hline $\min$ & $5.51 \cdot 10^{-11}$ & $3,78 \cdot 10^{-7}$ & $1,25 \cdot 10^{-8}$ & $6,04 \cdot 10^{-8}$ & $6,44 \cdot 10^{-9}$ & $5,51 \cdot 10^{-11}$ \\
\hline$X-\sigma$ & $4.29 \cdot 10^{-7}$ & $2,50 \cdot 10^{-6}$ & $1,07 \cdot 10^{-6}$ & $4,33 \cdot 10^{-7}$ & $4,27 \cdot 10^{-8}$ & $4,53 \cdot 10^{-7}$ \\
\hline log K standard deviation $\sigma$ & 1.39 & 1.08 & 1.38 & 1.22 & 1.42 & 1.35 \\
\hline \multirow[t]{2}{*}{ median } & $9.45 \cdot 10^{-6}$ & $6,17 \cdot 10^{-5}$ & $3,41 \cdot 10^{-5}$ & $3,54 \cdot 10^{-6}$ & $2,41 \cdot 10^{-6}$ & $6,92 \cdot 10^{-6}$ \\
\hline & \multicolumn{6}{|c|}{$\mathrm{T}\left[\mathrm{m}^{2} \cdot \mathrm{s}^{-1}\right]$} \\
\hline geometrical mean-X & $6.16 \cdot 10^{-4}$ & $1,70 \cdot 10^{-3}$ & $1,71 \cdot 10^{-3}$ & $2,27 \cdot 10^{-4}$ & $3,99 \cdot 10^{-5}$ & $7,64 \cdot 10^{-4}$ \\
\hline$X+\sigma$ & $1.24 \cdot 10^{-2}$ & $2,26 \cdot 10^{-2}$ & $2,96 \cdot 10^{-2}$ & $3,62 \cdot 10^{-3}$ & $4,78 \cdot 10^{-4}$ & $1,32 \cdot 10^{-2}$ \\
\hline $\max$ & $1.19 \cdot 10^{\circ}$ & $7,41 \cdot 10^{-2}$ & $1,19 \cdot 10^{0}$ & $9,52 \cdot 10^{-2}$ & $2,37 \cdot 10^{-3}$ & $1,46 \cdot 10^{-1}$ \\
\hline $\min$ & $6.12 \cdot 10^{-9}$ & $1,19 \cdot 10^{-5}$ & $1,09 \cdot 10^{-6}$ & $3,65 \cdot 10^{-6}$ & $3,61 \cdot 10^{-7}$ & $6,12 \cdot 10^{-9}$ \\
\hline$X-\sigma$ & $3.05 \cdot 10^{-5}$ & $1,28 \cdot 10^{-4}$ & $9,89 \cdot 10^{-5}$ & $1,42 \cdot 10^{-5}$ & $3,32 \cdot 10^{-6}$ & $4,40 \cdot 10^{-5}$ \\
\hline $\log T$ standard deviation $\sigma$ & 1.30 & 1,12 & 1,24 & 1,20 & 1,08 & 1,24 \\
\hline median & $7.58 \cdot 10^{-4}$ & $2,96 \cdot 10^{-3}$ & $2,11 \cdot 10^{-3}$ & $1,47 \cdot 10^{-4}$ & $2,47 \cdot 10^{-5}$ & $1,10 \cdot 10^{-3}$ \\
\hline number of evaluated wells & 238 & 13 & 63 & 34 & 19 & 92 \\
\hline
\end{tabular}




\section{SUMMARY}

Transmissivity $\boldsymbol{T}$ and hydraulic conductivity $\boldsymbol{K}$ data used in this paper were derived from specific capacity by described, relatively complex re-interpretation process, eliminating influences of differently performed pumping tests and taking into account hydraulic resistivities of both wells and aquifers. Using such an approach, it is still not possible to differentiate the values of transmissivity and hydraulic conductivity of conduits or fractures from the matrix in double-porosity carbonates. However, in lack of relevant data, any estimate of hydraulic conductivity or transmissivity - at least its "bulk value", can help to solve some practical problems. Data on hydraulic properties of these hard rocks show lognormal statistical distribution and a relatively high heterogeneity.

Comparing the mean values from 797 pumping tests on boreholes, we observed low transmissivity for granitoids (geometrical mean of $6.51 \cdot 10^{-5} \mathrm{~m}^{2} \cdot \mathrm{s}^{-1}$ ), and in one order of magnitude higher for limestones $\left(6.16 \cdot 10^{-4} \mathrm{~m}^{2} \cdot \mathrm{s}^{-1}\right)$. Aperture widening of fractures and joints in limestones by karstification - dissolution and abrasion - seem to be the reason for this. The highest mean transmissivity values were found for dolomitic aquifers $\left(1.04 \cdot 10^{-3} \mathrm{~m}^{2} \cdot \mathrm{s}^{-1}\right)$. In this case, all dolomites were of Middle/Upper Triassic age (Slovakian West Carpathians), diagenetically consolidated into rigid masses and afterwards tectonically reworked to form densely fissured aquifers.

Some particular lithological types, for which sufficient amount of data was found, were also analysed. Uniformity of all dolomitic aquifers types (all of them of Middle/Upper Triassic age) was found. Some limestone species, such as Steinalm and Raming, seem to have lower transmissivity and hydraulic conductivity in comparison with other types of limestones.
In this paper, aquifer properties were compared only for carbonate aquifer stratigraphies and lithologies. However, there are much more factors that are influencing transmissivity and permeability especially in hard rocks and karst aquifers. Such studies were performed on igneous or metamorphic rocks (Mabee 1999; Henrikssen 2003; Razack \& Lasm 2006) or dolomites (Verbovšek \& Veselič 2008). Authors of these tried to geostatistically correlate such factors as depth to the water table, overburden properties, overburden thickness, precipitation, net precipitation, runoff, regional stress fields, geormophological position or proximity to rivers with well yields, specific capacities or transmissivities. In many cases, achieved and described outputs of these studies represent an inspiration for further studies with the existing dataset. Factors as regional stress fields, fault zones or geormophology, should be investigated in close detail. For rocks affected by karstification processes, the extreme heterogeneity of hydraulic parameters is obvious - the probability of catching a major conduit by a borehole and subsequent hydraulic testing of the dominant hydraulic element in the rock mass is very low: 1 to 5\% (Klimchouk et al. 2000; Zwahlen et al. 2004). Having also in mind practical experience, that the "bulk hydraulic behaviour" of a karst or fissure aquifer system is governed by the most permeable unit within the rock environment, data from upper interval limits (maybe $\mathbf{X}+\boldsymbol{\sigma}$ ) should be used in simplified solutions. The presented results from borehole pumping tests dataset in karstified rocks do not show the real hydraulic values for karstified rocks, but serve as an example of their irregular distribution.

\section{ACKNOWLEDGEMENTS}

Database of wells and hydrogeological boreholes was developed under the scope of the project "Integrated Land Management", supervised by the Section of Geology and Natural Resources of the Ministry of Environment of Slovak Republic. The enormous effort in appropriate processing, sorting and evaluating data on 22,922 hydrogeological boreholes was made by Mr. Peter Bajtoš, Mr. Stanislav Olekšák, Ms. Soňa Cicmanová, Mr. František Bottlik, Ms. Erika Kováčová, Ms. Katarína Benková, Mr. Daniel Marcin, Mr. Juraj Michalko, Ms. Silvia Vojtková, Ms. Jana
Miklasová-Macháčková, Ms. Lubica Baranovičová, Ms. Mariana Sopková, Ms. Anna Tlučáková, Ms. Adriana Kamenická and Ms. Natália Bahnová-Kadlečíková. Both positive attitude of the aforementioned Ministry, as well as all database builders for the thoroughgoing approach are gratefully acknowledged. The authors would also like to acknowledge the valuable comments of Timotej Verbovšek and Bartolomé Andreo, the reviewers which helped us to significantly improve this paper by very constructive comments. 


\section{REFERENCES}

Busch, K.F. \& L. Luckner, 1972: Geohydraulik.- [in German] VEB Deutscher Verlag für Grundstoffindustrie, pp. 491, Leipzig.

El-Naqa, A., 1994: Estimation of transmissivity from specific capacity data in fractured carbonate rock aquifer, central Jordan.- Environmental Geology, $23,73-80$.

Hamm, S-Y., Cheong, J-Y., Jang, S., Jung, C-Y. \& B-S. Kim, 2005: Relationship between transmissivity and specific capacity in the volcanic aquifers of Jeju Island, Korea.- Journal of Hydrology, 310, 1-4, 111-121.

Helma, J., 2005: Vplyv litoštruktúrnych faktorov na hydrogeologický potenciál podzemných vôd veporika Čiernej hory. [The Influence of Lithological and Structural factores on the Groundwater Hydrogeological Potential in the Čierna Hora Veporic Unit. (in Slovak)].- PhD thesis. Faculty of Mining, Ecology, Management and Geotechnologies (BERG), Technical University Košice, pp. 282.

Helma, J., 2007: Hydraulické parametre sečenského šlíru lučenského súvrstvia. [Hydraulic parameters of the Szécsény schlier unit of the Lučenec formation (in Slovak with English summary)].- Podzemná voda, XIII, č.2/2007, 193-203.

Henriksen, H., 2003: The role of some regional factors in the assessment of well yields from hard-rock aquifers of Fennoscandia.- Hydrogeology Journal, 11, 628-645.

Jacob, C.E., 1944: Notes on determining permeability by pumping tests under water-table conditions.- USGS Open File Report, pp. 4, Washington DC.

Jacob, C.E., 1946: Drawdown test to determine effective radius of artesian well.- Trans. Amer. Soc. Civ. Engrs., 112, pap. 2321, 1047-1070.

Jetel, J., 1964: Použití hodnot specifické výdatnosti a nových odvozených parametrů $\mathrm{v}$ hydrogeologii. [Application of the specific capacity values and the new derivated parameters in hydrogeology (in Czech)].- Geol. Průzk., 6, 5, 144-145.

Jetel, J., 1982: Určování hydraulických parametrů hornin hydrodynamickými zkouškami ve vrtech. [Estimation of rock hydraulic properties by hydrodynamic tests in boreholes (in Czech)].- Knihovna ÚÚG, sv. 58, Ústřední Ústav Geologický, Academie ČSAV, pp. 246, Praha.

Jetel, J., 1985: Metody regionálního hodnocení hydraulických vlastností hornin. [Methods of the regional estimation of hydraulic properties of rocks (in Czech)].- Metodické prríručky ÚÚG, sv. 1, Ústřední Ústav Geologický, pp. 147, Praha.
Jetel, J., 1989: Relationship between hydrogeochemical characteristics of near-surface zone of rock massif and hydrodynamic conditions.- Západ. Karpaty, sér. Hydrogeol. Inž. Geol., 8, 67-104.

Jetel, J., 1990: Praktické dôsledky priestorovej neuniformity prietočnosti pripovrchovej zóny $\mathrm{v}$ hydrogeologickom massive. [Practical implications of the spatial non-uniformity of transmissivity in the near-surface zone of the hydrogeological massive (in Slovak)].- Geol. Průzk., 32, 2, 42-46.

Jetel, J., 1994: Priepustnost' a prietočnost̉ pripovrchovej zóny západného úseku flyšového pásma Západných Karpát. [Permeability and transmissivity of the near surface zone in the western part of Flych Belt in West Carpathians (in Slovak)].- Západné Karpaty, sér. Hydrogeol., Inž. Geol., Geoterm. Energia, 12, 7-62.

Jetel, J., 1995a: Utilizing Data on Specific Capacities of Wells and Water-Injection Rates in Regional Assessment of Permeability and Transmissivity.- Slovak Geological Magazine, 1-95, 7-18.

Jetel, J., 1995b: Acquisition of data for regional assessment of permeability and transmissivity.- In: Proc. I. Hrvat. geol. kongr., Opatija 1995, Zbornik radova, 1, 251-254, Zagreb.

Jetel, J. \& J. Krásný, 1968: Approximative aquifer characteristics in regional hydrogeological study.- Věst. Ústřr. Úst. Geol., 51, 1, 47-50.

Káčer, Š. (ed.), Polák, M., Bezák, V., Hók, J., Teták, F., Konečný, V., Kučera, M., Žec, B., Elečko, M., Hraško, L., Kováčik, M., Pristaš, J., Káčer, Š., Antalík, M., Lexa, J., Zvara, I., Fritzman, R., Vlachovič, J., Bystrická, G., Brodianska, M., Potfaj, M., Madarás, J., Nagy, A., Maglay, J., Ivanička, J., Gross, P., Rakús, M., Vozárová, A., Buček, S., Boorová, D., Šimon, L. \& J. Mello, 2005: Slovenská republika - digitálna geologická mapa v M 1:50,000 a 1:500,000. [Slovak Republic - digital geological map in 1:50,000 and 1:500,000 (in Slovak)].- Manuscript, Archive of Geofond - the informatics branch of State Geological Institute of Dionyz Stur, pp. 42, Bratislava.

Klimchouk, A.B., Ford, D.C., Palmer, A.N. \& W. Dreybrodt (eds.), 2000: Speleogenesis. Evolution of Karst Aquifers.- National Speleological Society, Inc., pp. 527, Alabama, USA.

Kresic, N., 2007: Hydraulic methods.- In: Goldscheider, N. \& D. Drew (eds.) Methods in Karst Hydrogeology. International contributions to hydrogeology, 26, International Association of Hydrogeologists, Taylor \& Francis, pp. 65-92, London. 
Mabee, S.B., 1999: Factors Influencing Well Productivity in Glaciated Metamorphic Rocks.- Ground Water, 37, 1, 88-97.

Mace, R.E., 1997: Determination of Transmissivity from Specific Capacity Tests in a Karst Aquifer.- Ground Water, 35, 5, 738-742.

Schulze-Makuch, D., Carlson, D.A., Cherkauer, D.S. \& P. Malík, 1999: Scale Dependency of Hydraulic Conductivity in Heterogeneous Media.- Ground Water, 37, 6, 904-919.

Malík, P. (ed.), Bačová, N., Hronček, S., Ivanič, B., Kočický, D., Maglay, J., Malík, P., Ondrášik, M., Šefč́k, P., Černák, R., Švasta, J. \& J. Lexa, 2007: Zostavovanie geologických máp v mierke 1:50 000 pre potreby integrovaného manažmentu krajiny. [Composition of geological maps in scale 1:50,000 for the landscape management needs (in Slovak)].- Manuscript, Archive of Geofond branch of State Geological Institute of Dionyz Stur, pp. 552, Bratislava.

Map server of the State Geological Institute of Dionyz Stur, 2008: Geological Survey of Slovak Republic Bratislava, Slovakia. Digital geological map in the scale of 1 : 50 000.- [Online] Available from: http:// www.geology.sk/index.php?pg=geois.mapovy_server [Accessed $2^{\text {nd }}$ May 2008].

Olekšák, S., 2004: Využitie nepriamych metód hodnotenia priemernej prietočnosti a priepustnosti $v$ horských oblastiach neovulkanitov.- [The Use of Indirect Methods of Mean Transmissivity and Hydraulic Conductivity Estimation in Mountainous Volcanic Areas (in Slovak)]. PhD thesis. Faculty of Natural Sciences, Comenius University, Bratislava, pp. 80.
Razack, M. \& T. Lasm, 2006: Geostatistical estimation of the transmissivity in a highly fractured metamorphic and crystalline aquifer (Man-Danane Region, Western Ivory Coast).- Journal of Hydrology, 325, 1-4, 164-178.

Šarin, A., 1990: Deteminantion of approximate geohydraulic parameters of sedimentary rocks from their electrical resistivity.- In: Livro de Homenagem a Carlos Romariz, Proc., Dep. de Geol., Fac. de Cien, 103-114, Lisboa.

Theis, C.V., 1963: Estimating the transmissivity of a water-table aquifer from the specific capacity of a well.- U.S. Geological Survey Water Supply Paper, 1536-I, 332-336.

Thomasson, H.J., Olmstead, F.H. \& E.R. LeRoux, 1960: Geology, water resources, and usable ground water storage capacity of part of Solano County, CA.U.S. Geological Survey Water Supply Paper 1464, pp. 693

Verbovšek, T., 2008: Estimation of transmissivity and hydraulic conductivity from specific capacity and specific capacity index in dolomite aquifers.- Journal of Hydrologic Engineering, 13, 9, 817-823. DOI: 10.1061/(ASCE)1084-0699(2008)13:9(817).

Verbovšek, T. \& M. Veselič 2008: Factors influencing the hydraulic properties of wells in dolomite aquifers of Slovenia.- Hydrogeology Journal, 16, 779-795

Zwahlen, F. (ed.), 2004: Vulnerability and Risk Mapping for the Protection of Carbonate (Karst) Aquifers.COST Action 620 Final Report. Office for Official Publications of the European Communities, XVIII, pp. 297, Luxembourg. 